University of Nebraska - Lincoln

DigitalCommons@University of Nebraska - Lincoln

Papers in the Earth and Atmospheric Sciences Earth and Atmospheric Sciences, Department

2010

\title{
Melting Alpine Glaciers Enrich High-Elevation Lakes with Reactive Nitrogen
}

Jasmine E. Saros

University of Maine - Main, jasmine.saros@maine.edu

Kevin C. Rose

Miami University - Oxford

David W. Clow

U.S. Geological Survey

Verlin C. Stevens

U.S. Geological Survey

Andrea B. Nurse

University of Maine - Main

See next page for additional authors

Follow this and additional works at: https://digitalcommons.unl.edu/geosciencefacpub

Part of the Earth Sciences Commons

Saros, Jasmine E.; Rose, Kevin C.; Clow, David W.; Stevens, Verlin C.; Nurse, Andrea B.; Arnett, Heather A.; Stone, Jeffery R.; Williamson, Craig E.; and Wolfe, Alexander P., "Melting Alpine Glaciers Enrich HighElevation Lakes with Reactive Nitrogen" (2010). Papers in the Earth and Atmospheric Sciences. 119. https://digitalcommons.unl.edu/geosciencefacpub/119

This Article is brought to you for free and open access by the Earth and Atmospheric Sciences, Department of at DigitalCommons@University of Nebraska - Lincoln. It has been accepted for inclusion in Papers in the Earth and Atmospheric Sciences by an authorized administrator of DigitalCommons@University of Nebraska - Lincoln. 
Authors

Jasmine E. Saros, Kevin C. Rose, David W. Clow, Verlin C. Stevens, Andrea B. Nurse, Heather A. Arnett, Jeffery R. Stone, Craig E. Williamson, and Alexander P. Wolfe 
Melting Alpine Glaciers Enrich High-Elevation Lakes with Reactive Nitrogen

\author{
JASMINE E. SAROS, ${ }^{*}{ }^{\dagger}$ KEVIN C. ROSE, \\ DAVID W. C L OW, $\$$ \\ VERLIN C. STEPHENS, \\ ANDREA B. NURSE, ${ }^{\dagger}$ \\ HEATHER A. ARNETT, ${ }^{\dagger}$ \\ JEFFERY R. STONE," \\ CRAIG E. WILLIAMSON, ${ }^{\ddagger}$ AND \\ A LEXAN DER P. WO L F E ${ }^{\perp}$ \\ Climate Change Institute, University of Maine, \\ Orono, Maine 04469, Department of Zoology, Miami \\ University, Oxford, Ohio 45056, U.S. Geological Survey, Water \\ Resources Discipline, Lakewood, Colorado 80225, Department \\ of Geosciences, University of Nebraska-Lincoln, Lincoln, \\ Nebraska 68588, and Department of Earth \& Atmospheric \\ Sciences, University of Alberta, Edmonton, \\ Alberta T6G 2E3, Canada
}

Received January 14, 2010. Revised manuscript received May 26, 2010. Accepted May 28, 2010.

Alpine glaciers have receded substantially over the last century in many regions of the world. Resulting changes in glacial runoff not only affect the hydrological cycle, but can also alter the physical (i.e., turbidity from glacial flour) and biogeochemical properties of downstream ecosystems. Here we compare nutrient concentrations, transparency gradients, algal biomass, and fossil diatom species richness in two sets of high-elevation lakes: those fed by snowpack melt alone (SF lakes) and those fed by both glacial and snowpack meltwaters (GSF lakes). We found that nitrate $\left(\mathrm{NO}_{3}{ }^{-}\right)$concentrations in the GSF lakes were 1-2 orders of magnitude higher than in SF lakes. Although nitrogen ( $\mathrm{N}$ ) limitation is common in alpine lakes, algal biomass was lower in highly N-enriched GSF lakes than in the N-poor SF lakes. Contrary to expectations, GSF lakes were more transparent than SF lakes to ultraviolet and equally transparent to photosynthetically active radiation. Sediment diatom assemblages had lower taxonomic richness in the GSF lakes, a feature that has persisted over the last century. Our results demonstrate that the presence of glaciers on alpine watersheds more strongly influences $\mathrm{NO}_{3}{ }^{-}$concentrations in high-elevation lake ecosystems than any other geomorphic or biogeographic characteristic.

\section{Introduction}

Changes in the volume of glacial runoff have been observed in alpine regions around the world $(1-4)$. These changes have important implications for solute flux to stream ecosystems (5-7) as well as the supply of freshwater to human

\footnotetext{
* Corresponding author phone: (207)581-2112; e-mail: jasmine.saros@maine.edu.

${ }^{\dagger}$ University of Maine.

‡ Miami University.

${ }^{\S}$ U.S. Geological Survey.

" University of Nebraska-Lincoln.

${ }^{\perp}$ University of Alberta.
}

populations $(8-10)$. Less is known, however, about how changes in the influx of glacial meltwater affect the chemistry (11) and biota of lake ecosystems. In the Canadian Rockies, melting alpine glaciers release concentrated organic pesticides into lake ecosystems and contribute $50-97 \%$ of the organochlorine inputs to these systems, resulting in higher concentrations relative to nonglacial lakes (12). In the southern Rocky Mountains of North America, an area with relatively high atmospheric reactive $\mathrm{N}(\mathrm{Nr})$ deposition $(4-8$ $\mathrm{kg} \mathrm{N} \mathrm{ha}^{-1} \mathrm{yr}^{-1}$ ), meltwaters from ice and rock glaciers have elevated nitrate concentrations (13). Lake-water $\mathrm{NO}_{3}{ }^{-}$concentrations are also high in this area, but because of relatively high $\mathrm{Nr}$ deposition $(7,14)$, the extent to which meltwater from ice and rock glaciers contribute $\mathrm{Nr}$ remains unclear. Nitrogen is a key limiting nutrient in alpine lake ecosystems $(15,16)$, hence an influx of nitrate-rich glacial meltwater could have profound effects on productivity and species diversity in historically $\mathrm{N}$-limited alpine lakes. Here we focus on $\mathrm{NO}_{3}{ }^{-}$ concentrations in glacial meltwater and its effects on highelevation lake ecosystems in two low $\mathrm{N}$ deposition areas of the U.S. Rocky Mountains: the Greater Yellowstone Ecosystem (central Rockies) and Glacier National Park (northern Rockies) (Figure 1). The selected sites in the central Rockies have a combined rate of $\mathrm{NO}_{3}{ }^{-}$and ammonium $\left(\mathrm{NH}_{4}{ }^{+}\right)$deposition between $1.4-2.5 \mathrm{~kg} \mathrm{Nr} \mathrm{ha}^{-1}$ year $^{-1}$, while those in the northern Rockies are between $2.0-3.4 \mathrm{~kg} \mathrm{Nr} \mathrm{ha}^{-1}$ year $^{-1}$ (17). Alpine glaciers receded substantially in both regions over the course of the 20th century $(18-20)$.

\section{Experimental Procedures}

Watershed land cover classes were delineated for 26 watersheds across the two study areas using the Northwest GAP Analysis classes (21), which included perennial ice and snow (denoted North American Alpine Ice Field in the Northwest GAP classes), bedrock, talus, and 18 types of vegetation (Supporting Information (SI) Table S-1 provides a complete list of the 21 land cover classes). A geographic information system (GIS) was used to delineate watersheds using a $30 \mathrm{~m}$ digital elevation model, and to calculate basin and climatic predictor variables using various GIS techniques for each of the watersheds. Predictor variables included mean nitrate deposition, watershed area, land use, and precipitation derived from multiple data sources $(17,21-23)$. Perennial ice and snow cover was present on 14 watersheds. Of these, 12 had named (seven watersheds) or unnamed (five watersheds) glaciers delineated on U.S. Geological Survey base maps (from 1956 for Beartooth region, 1968 for Glacier National Park); the 12 lakes in this group were denoted as GSF. During our fieldwork, we were able to confirm the presence of glacial ice for nine of these; we were unable to reach the locations for the remaining three. We note here that the GIS analysis does not distinguish active glaciers from ice that has become stagnant. Assuming that new glaciers have not formed in the last 50 years, we inferred that, for the remaining two (Two Medicine and Beauty) of 14 watersheds with perennial ice and snow cover, they have perennial snow. These two lakes were thus categorized as SF systems along with those situated on the remaining 12 watersheds without any perennial ice and snow cover.

We sampled the dissolved nutrient chemistry of the 14 SF and 12 GSF lakes along with as many accessible inlet streams as possible entering these lakes. Lake water samples were collected from the pelagic zone using a van Dorn bottle deployed from a rubber raft. All 26 lakes were sampled in mid- to late July; a subset of six lakes (two GSF, four SF) was 


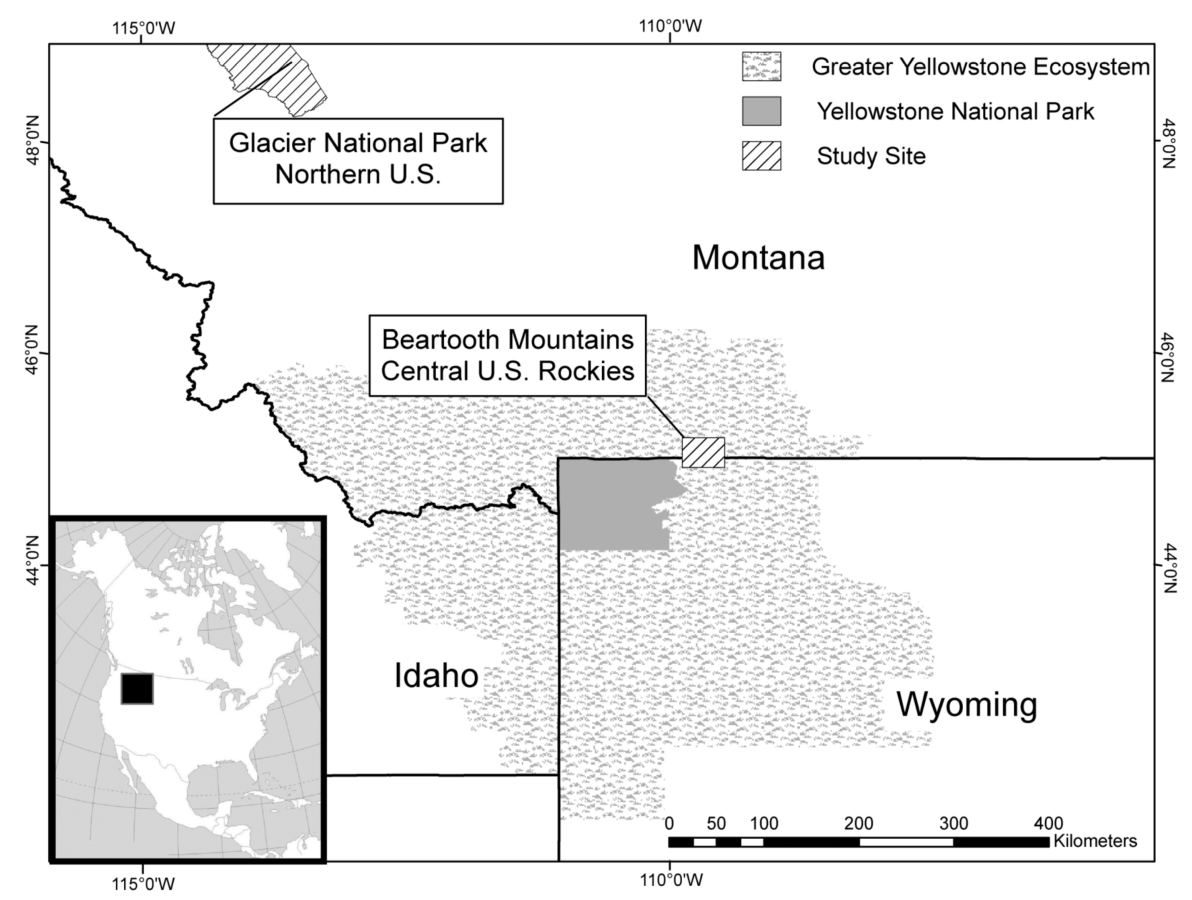

FIGURE 1. Map of the study region in the U.S. Rocky Mountains. Lakes in the central Rockies are located in the Beartooth Mountain Range, which is part of the Greater Yellowstone Ecosystem. Lakes in the northern Rockies are located in Glacier National Park, which is part of the Crown of the Continent Ecosystem.

resampled during the last half of August. Inlet stream and glacial meltwater samples were collected by submerging an $\mathrm{HCl}$ acid-washed bottle (prerinsed three times with sample water) into the lake or stream. All water samples for nutrient analyses were filtered through $0.4 \mu \mathrm{m}$ polycarbonate membranes prerinsed with deionized water. $\mathrm{NO}_{3}{ }^{-}-\mathrm{N}$ was quantified using the cadmium reduction method on a Lachat QuikChem 8500 flow injection analyzer with a limit of quantification of $1 \mu \mathrm{g} \mathrm{N} \mathrm{L}{ }^{-1}$. Matrix interferences were tested by spiking an aliquot of sample from each lake with $50 \mu \mathrm{g}$ $\mathrm{NO}_{3}{ }^{-}-\mathrm{N} \mathrm{L}^{-1}$; percent recovery ranged from 78 to $98 \%$ across samples. Soluble reactive phosphorus (SRP) was measured using the ascorbic acid method with a limit of quantification of $1 \mu \mathrm{g} \mathrm{P} \mathrm{L} \mathrm{L}^{-1}$. Dissolved silica was measured with the heteropoly blue method.

$\mathrm{NO}_{3}{ }^{-}$concentrations in the ice and surface meltwater of Sundance Glacier, situated near one of the GSF lakes in the central Rockies, were also measured. Ice from Sundance Glacier was collected by first scraping away a thin layer of surface debris with acid-washed polycarbonate spatulas, then using a hammer and acid-washed chisel to remove a piece of ice, which was then allowed to melt in an acid-washed bottle.

For a subset of lakes ( $n=9$ for each lake type), we examined key physical and biological metrics. Total algal biomass was measured as chlorophyll $a$; samples were collected onto Whatman GF/F filters, frozen, extracted in acetone, and measured with a Turner Designs Trilogy fluorometer. Material retained on polycarbonate filters was analyzed for particulate $\mathrm{P}$ by persulfate digestion followed by measurement of SRP as above. A conservative estimate of total P was obtained by summing these fractions (as in ref 16). Water-column transparency to ultraviolet radiation (UVR, measured at $320 \mathrm{~nm}$ ) and photosynthetically active radiation (PAR, 400-700 nm) were quantified with a Biospherical Instruments Cosine (BIC) submersible radiometer and $1 \%$ depths estimated from diffuse attenuation coefficients (24). Logistical constraints resulted in $n=8$ per lake type for the light profiles. We also determined concentrations of dissolved organic carbon (DOC), as this material can play an important role in attenuating light in lake ecosystems (25). Epilimnetic
(2-3 m depth) water samples for DOC were filtered through precombusted Whatman GF/F filters and stored in the cold and dark until analysis with a Shimadzu TOC- $\mathrm{V}_{\mathrm{CPH}}$ Total Organic Carbon Analyzer (as in ref 26).

Diatoms (Bacillariophyceae) are unicellular photoautotrophic algae that are highly sensitive to changes in nutrient concentrations, and often dominate primary production in oligotrophic lakes $(27,28)$. We determined diatom community structure in surface sediments of the subset of 18 lakes as well as down-core assemblages in six lakes (three GSF, three SF). Surface sediment samples were collected in 2007; long cores were collected in 2001 or 2007. Methods for the collection and dating of sediment cores are previously described $(16,29)$. Taxonomic richness of diatom communities in the surface sediments and down-core assemblages was calculated by rarefaction analysis of species-level data (30). The dominant pattern of down-core assemblage variability was also quantified with the leading axis of detrended correspondence analyses (DCA (31)) for each cored lake. DCA was conducted on the relative frequencies (\% of sum counted) of all diatoms $>1 \%$ in any one sample.

One-way analysis of variance (ANOVA) tests were used to compare various characteristics of GSF versus SF lakes; Levene's test for homogeneity was used in all cases. Data that were not normally distributed were log transformed; if this failed to improve normality, we conducted nonparametric one-way ANOVA using Wilcoxon (Kruskal-Wallis) scores. Spearman's rank correlation analysis was used to examine the relationships between lake water nitrate concentrations and the 21 watershed characteristics, with a Bonferroni correction applied $(p=0.05 / 21=0.002)$.

\section{Results and Discussion}

A summary of select watershed features of the GSF and SF lakes reveals that lakes in the two categories have similar ranges in elevation and position with respect to treeline (Table 1 , with the full data set in SI Table S-2). Compared to watersheds of SF lakes, GSF watersheds have a higher percent cover by perennial ice and snow $(p<0.001)$ as well as by bedrock and talus $(p=0.06)$. 
TABLE 1. Select Watershed Characteristics of the Study Lakes. Average Values for Elevation and Percent Watershed Coverage by Perennial Ice and Snow As Well As Bedrock and Talus Are Indicated, with the Range of Data Provided in Parentheses ${ }^{a}$

\begin{tabular}{|c|c|c|c|c|c|c|}
\hline \multirow[b]{2}{*}{ lake type } & \multirow[b]{2}{*}{ elevation (m a.s.I.) } & \multirow[b]{2}{*}{$\%$ perennial ice and snow } & \multirow[b]{2}{*}{$\%$ bedrock and talus } & \multicolumn{3}{|c|}{ treeline } \\
\hline & & & & $\mathrm{Be}$ & $\mathrm{Tr}$ & $\overline{\mathbf{A b}}$ \\
\hline $\begin{array}{l}\text { GSF } \\
\text { SF }\end{array}$ & $\begin{array}{l}2047(1191-3094) \\
2574(1576-3144)\end{array}$ & $\begin{array}{l}2.25(0.01-10.1) \\
0.008(0-0.1)\end{array}$ & $\begin{array}{l}13.1(5.9-26.2) \\
6.8(0-28.4)\end{array}$ & $\begin{array}{l}8 \\
7\end{array}$ & $\begin{array}{l}2 \\
3\end{array}$ & $\begin{array}{l}2 \\
4\end{array}$ \\
\hline
\end{tabular}

${ }^{a}$ Position of lakes with respect to treeline is indicated as number below (Be), at ( $\mathrm{Tr}$ ), or above (Ab). A full table of these values, as well as lake water chemistry, is provided in SI Table S-2.

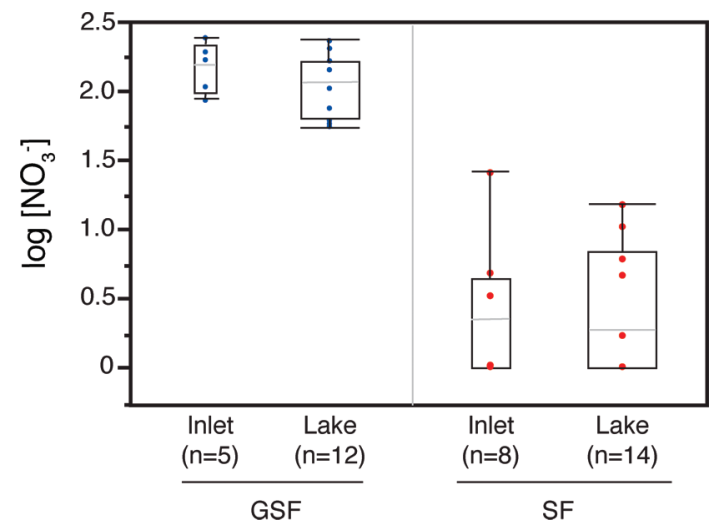

FIGURE 2. Comparison of $\log \left[\mathrm{NO}_{3}{ }^{-}\right]$between GSF lakes and inlet streams and SF counterparts. Boxes represent the lower and upper quartiles, whiskers indicate the range of measurements, and gray bars indicate the mean in each category. Values below the detection limit of $1 \mu \mathrm{g} \mathrm{NO}{ }_{3}^{-}-\mathrm{N} \mathrm{L}^{-1}$

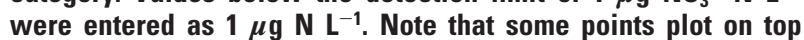
of each other.

TABLE 2. Comparison of July and August $\mathrm{NO}_{3}{ }^{-}$Values (in $\mu \mathrm{g}$ $\mathrm{NO}_{3}^{-}-\mathrm{N} \mathrm{L}^{-1}$ ) for Two GSF and Four SF lakes in the Beartooth Mountains

\begin{tabular}{clcc} 
lake type & Lake & July & August \\
GSF & Rainbow & 139 & 121 \\
& Glacier & 90 & 84 \\
& Beartooth & 2 & 2 \\
SF & Beauty & 1 & $<1$ \\
& Island & 4 & $<1$ \\
& Fossil & 1 & $<1$ \\
\hline
\end{tabular}

Across the 26 lakes in this study, $\mathrm{NO}_{3}{ }^{-}$concentrations were higher in the GSF compared to the SF lakes (nonparametric one-way ANOVA, $p<0.0001$; Figure 2). The average $\mathrm{NO}_{3}{ }^{-}$concentration of the GSF lakes was $114 \pm 17 \mu \mathrm{g} \mathrm{N} \mathrm{L}^{-1}$ (range: $52-236 \mu \mathrm{g} \mathrm{NO}_{3}{ }^{-}-\mathrm{N} \mathrm{L}^{-1}$ ), while the average of the SF lakes was very low at $4 \pm 1 \mu \mathrm{g} \mathrm{N} \mathrm{L}^{-1}$ (range: $<1-14 \mu \mathrm{g} \mathrm{NO}_{3}{ }^{-}-\mathrm{N}$ $\mathrm{L}^{-1}$ ). $\mathrm{NO}_{3}{ }^{-}$concentrations were also higher in the inlet streams of the GSF lakes (i.e., streams draining from alpine glaciers) compared to those of SF lakes $(p<0.0001$; Figure 2). The average $\mathrm{NO}_{3}{ }^{-}$concentration of the GSF inlets was $158 \pm 30$ $\mu \mathrm{g} \mathrm{N} \mathrm{L}^{-1}$ (range: $82-250 \mu \mathrm{g} \mathrm{NO}_{3}{ }^{-}-\mathrm{N} \mathrm{L}^{-1}$ ), while the average of the SF inlets was $5 \pm 3 \mu \mathrm{g} \mathrm{N} \mathrm{L}^{-1}$ (range: $<1-26 \mu \mathrm{g} \mathrm{NO}_{3}{ }^{-}$-N $\left.\mathrm{L}^{-1}\right)$. SRP concentrations were below detection $\left(<1 \mu \mathrm{g} \mathrm{PO}_{4}{ }^{-3}-\mathrm{P}\right.$ $\mathrm{L}^{-1}$ ) in all streams and lakes, except in one SF lake (Heart, $\left.\mathrm{SRP}=1 \mu \mathrm{g} \mathrm{P} \mathrm{L}^{-1}\right)$. Silica concentrations did not differ between the two lake types (GSF lakes: $1794 \pm 176 \mu \mathrm{g} \mathrm{Si} \mathrm{L}^{-1}$, SF lakes: $1511 \pm 198 \mu \mathrm{g} \mathrm{Si} \mathrm{L}{ }^{-1} ; p=0.30$ ). July and August lake water $\mathrm{NO}_{3}{ }^{-}$concentrations were similar in the subset examined (Table 2), suggesting that later snowmelt did not account for the higher $\mathrm{NO}_{3}{ }^{-}$concentrations in GSF lakes in July.

Out of 21 types of land cover quantified for each watershed in this study, only percent perennial ice and snow cover correlated significantly with lake water $\mathrm{NO}_{3}{ }^{-}$concentrations

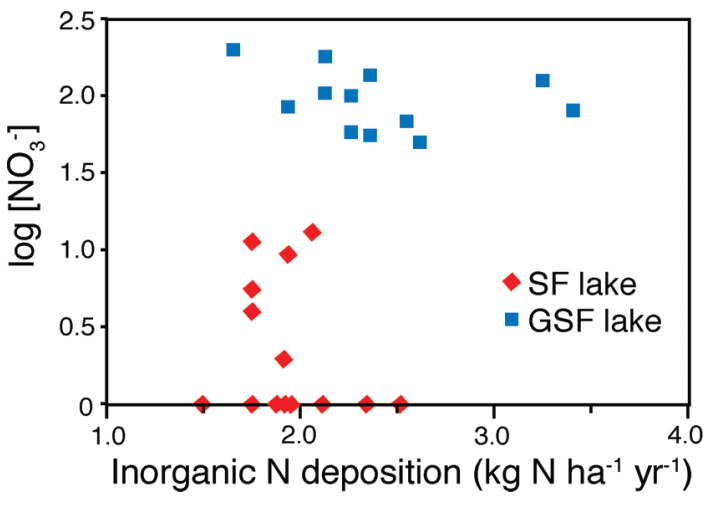

FIGURE 3. Comparison of lake water $\log \left[\mathrm{NO}_{3}{ }^{-}\right]$to total wet inorganic nitrogen deposition calculated for each site. Data for GSF lakes are blue squares, while those for SF lakes are red diamonds.

(Spearman's $\rho=0.63, p=0.001$ ). A linear relationship between percent perennial ice and snow cover and lake water $\mathrm{NO}_{3}{ }^{-}$concentrations was not apparent (data shown in SI Table S-2); rather it is the presence-absence of alpine glaciers that is associated with high versus low nitrate concentrations, respectively. While the percent of remaining perennial ice and snow cover is lower in the central Rockies relative to sites to the north, $\mathrm{NO}_{3}{ }^{-}$concentrations in GSF lakes were comparable in both areas. Rather than the percent of watershed covered by perennial ice and snow, $\mathrm{NO}_{3}{ }^{-}$concentrations in GSF lakes may relate more strongly to metrics such as the current mass of perennial ice on each watershed, the current rate of perennial ice retreat on each watershed, as well as the percent contribution of glacial runoff to the total hydrological budget of each lake; determining values for these metrics was beyond the scope of this study. While lichen communities that can fix nitrogen frequently dominate bedrock and talus habitat, the percent watershed cover by this habitat was not significantly correlated with lake water $\mathrm{NO}_{3}{ }^{-}$concentrations (Spearman's $\rho=0.43, p=0.03$ ) after applying the Bonferroni correction. We note that three of the SF lakes with undetectable $\mathrm{NO}_{3}{ }^{-}$concentrations had watersheds with more than $15 \%$ coverage by bedrock and talus, whereas nine of the GSF lakes had watersheds with less than $15 \%$ coverage by this habitat.

Estimated rates of current $\mathrm{Nr}$ deposition were not correlated with lake water $\mathrm{NO}_{3}{ }^{-}$in either region investigated (Figure 3). Although the central Rockies have a lower range of combined $\mathrm{NO}_{3}{ }^{-}+\mathrm{NH}_{4}{ }^{+}$deposition rates than the northern Rockies, lake water $\mathrm{NO}_{3}{ }^{-}$concentrations were not different between the two areas. Previous work in the SF lakes of the central Rockies revealed that enhanced atmospheric $\mathrm{Nr}$ deposition has altered diatom community structure in some lakes over recent decades, even though measurable changes in $\mathrm{NO}_{3}{ }^{-}$concentrations in these SF lakes are not yet apparent (16). While approximately half of the lakes in Glacier National Park receive glacial meltwater, we estimate that only about $10-20 \%$ of those in the central Rockies receive these inputs, hence the majority of lakes in this region are SF, likely have 


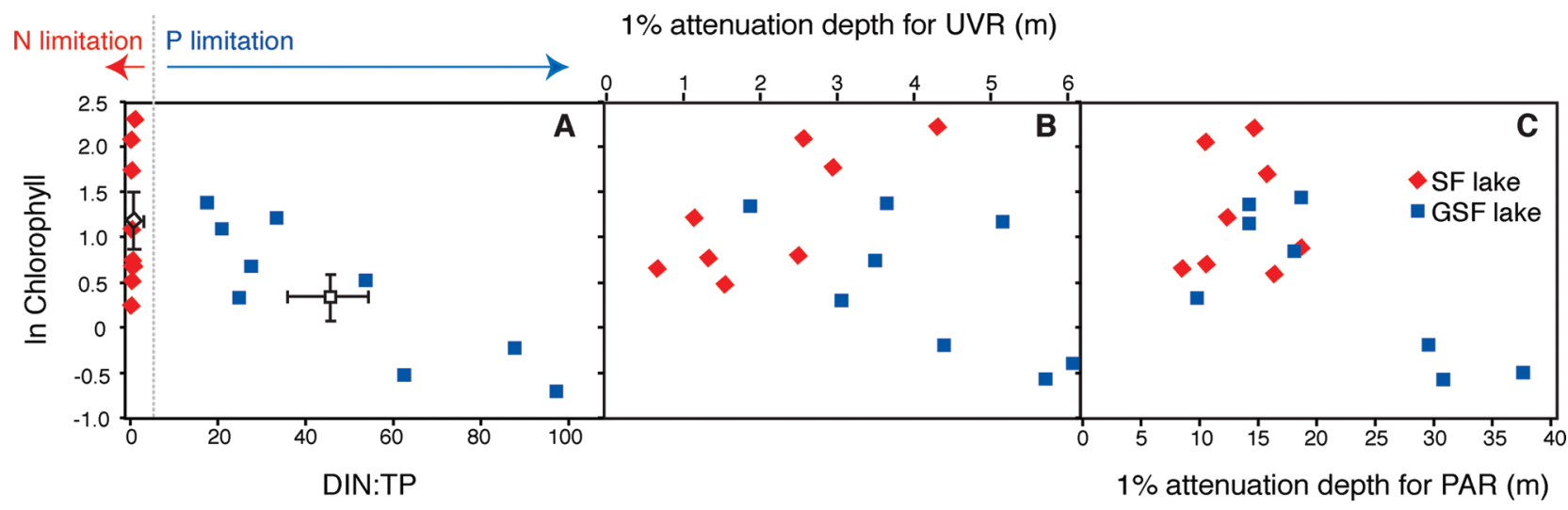

FIGURE 4. Relationships between algal biomass (as In[chlorophyll]) and selected lake characteristics. (A) dissolved inorganic nitrogen: total phosphorus (DIN:TP) ratio; $(B)$ the $1 \%$ attenuation depth for ultraviolet radiation (UVR, measured at $320 \mathrm{~nm}$ ); and (C) the $1 \%$ attenuation depth for photosynthetically active radiation (PAR; 380-700 nm). Data for GSF lakes are blue squares, while those for SF lakes are red diamonds. The mean \pm one standard error are indicated with an open symbol for each group in Panel $A$.

low $\mathrm{NO}_{3}{ }^{-}$concentrations, and thus remain susceptible to enhanced atmospheric Nr deposition.

The influx of N-rich glacial meltwater affects the structure and function of high-elevation lake ecosystems in several ways. Although algal growth is often $\mathrm{N}$-limited in alpine lakes $(15,16)$, algal biomass was lower in the N-rich GSF lakes than in the N-poor SF lakes ( $p=0.06$; Figure $4 \mathrm{a})$. The ratio of dissolved inorganic N: total phosphorus (DIN:TP (32)) suggests that SF lakes are N-limited, while GSF lakes are P-limited (Figure 4a). Chlorophyll levels declined in GSF lakes as the DIN:TP ratio increased $\left(r^{2}=0.75, p<0.001\right)$.

Lowered algal biomass can result from light limitation in lakes receiving high inputs of glacial flour. However, this was not the case in the investigated lakes, which are not in direct contact with glaciers but rather situated some distance from receding termini, thereby allowing for upstream trapping of minerogenic glacial sediment. Rather, we found the opposite: GSF lakes were more transparent than SF lakes to UVR ( $p=$ 0.02 ), and equally transparent to PAR ( $p=0.07)$. Furthermore, chlorophyll $a$ concentrations were lower in the more transparent GSF lakes (Figure $4 \mathrm{~b}$ and c). Average DOC concentrations were low in all lakes (SF lakes: mean $\pm \mathrm{SE}=$ $0.9 \pm 0.2 \mathrm{mg} \mathrm{L}^{-1}$; GSF lakes: $0.6 \pm 0.1 \mathrm{mg} \mathrm{L}^{-1}$ ); these differences were not statistically significant ( $p=0.07$ ).

Diatom species richness in surface-sediment samples from GSF lakes was lower than in the SF lakes (one-way ANOVA $p=0.008$; Figure 5a). Diatom taxonomic richness in down-core sediment records from GSF lakes was consistently low over the last century, ranging from 12 to 26 taxa (example from Rainbow Lake, Figure 5d). In contrast, species richness ranged from 35 to 54 in cores from SF lakes over the same interval (example from Beauty Lake, Figure 5b). While richness differed between Rainbow and Beauty, DCA scores reveal a similar degree of diatom community turnover in both lakes over the last century (Figure $5 b$ and d). However, abrupt declines in diatom richness and higher rates of community turnover are observed in SF lakes influenced by elevated Nr deposition (e.g., Emerald Lake, Figure 5c) (16). Emerald Lake, located in the Beartooth Wilderness, has among the highest $\mathrm{NO}_{3}{ }^{-}$concentrations recorded from any SF lake sampled: $10 \mu \mathrm{g} \mathrm{N} \mathrm{L}{ }^{-1}$. Diatom communities from this lake had initially high richness in the early 20th century, similar to other SF lakes, but then progressively declined as atmospheric Nr subsidies became pronounced (Figure $5 \mathrm{c}$ ). The analysis of diatom richness across both spatial and temporal scales indicates that species richness is lower in GSF lakes, and these lakes have experienced this effect for over a century.

It is not unexpected that alpine glacial meltwater contains $\mathrm{NO}_{3}{ }^{-}$, as glaciers accumulate a range of atmospherically delivered chemicals $(12,33) . \mathrm{NO}_{3}{ }^{-}$is also among the first ions to elute from melting glacier ice (34). The key question, however, is why glacial meltwaters in the central and northern Rockies are so enriched in $\mathrm{NO}_{3}{ }^{-}$. The limited data available on ice cores in this region are consistent with our observations. For example, ice from the Upper Fremont Glacier in the central Rocky Mountains (Wind River Range) contains variable amounts of $\mathrm{NO}_{3}{ }^{-}$over time, with concentrations occasionally above $10 \mu \mathrm{g} \mathrm{L} \mathrm{L}^{-1}$ between 1717 and 1985, and then in excess of $100 \mu \mathrm{g} \mathrm{L}^{-1}$ after 1985 (35). Samples that we collected from the Sundance Glacier revealed $\mathrm{NO}_{3}{ }^{-}$concentrations of $11 \mu \mathrm{g} \mathrm{N} \mathrm{L}^{-1}$ in the ice, $28 \mu \mathrm{g} \mathrm{N} \mathrm{L}^{-1}$ in a meltwater stream on the surface of the glacier, and $158 \mu \mathrm{g} \mathrm{N} \mathrm{L}^{-1}$ in a pond situated on the surface of the glacier, receiving the surface meltwater stream. Similar glacier ice $\mathrm{NO}_{3}{ }^{-}$concentrations occur at Taylor Glacier in the Colorado Front Range (7). Processes including the alpine distillery (36) as well as relatively high sublimation and evaporation rates on glaciers in alpine regions appear to concentrate $\mathrm{NO}_{3}{ }^{-}$in these environments, prior to delivering high $\mathrm{NO}_{3}{ }^{-}$meltwaters to downstream aquatic ecosystems. Evaporative concentration may explain the high $\mathrm{NO}_{3}{ }^{-}$concentration observed in ponded water on the Sundance Glacier.

The higher $\mathrm{NO}_{3}{ }^{-}$concentration of glacial meltwater relative to seasonal snowpack melt may also be due, in part, to its reduced contact with watershed soils where microbial communities may rapidly assimilate any available $\mathrm{Nr}$ (37). Channelization of supraglacial runoff implies that the bulk of solutes, whether preconcentrated or not, will be disseminated to meltwater streams with minimal intervening biological uptake. This contrasts to SF watersheds, where snowmelt percolates through soils before reaching streams. Additionally, nitrification of snow and icemelt $\mathrm{NH}_{4}{ }^{+}$in subglacial environments is a mechanism for $\mathrm{NO}_{3}{ }^{-}$production. Isotopic studies of aqueous $\mathrm{NO}_{3}{ }^{-}$in an Arctic glacier system on Svalbard revealed that this mechanism explained more than $80 \%$ of the increase in $\mathrm{NO}_{3}{ }^{-}$concentrations observed between supra- and subglacial streams, whereas contributions from rock-derived $\mathrm{NH}_{4}{ }^{+}$appeared minimal (38). Additional hypotheses, including those involving rock glaciers and landscape development, are discussed elsewhere $(7,13,39,40)$, although we note that our analysis of watershed characteristics did not reveal significantly different $\mathrm{NO}_{3}{ }^{-}$ contributions associated with the extent of talus or vegetation types across GSF versus SF watersheds. Determining the age of talus (Pleistocene versus Holocene neoglacial) across these watersheds may provide additional insight; studies in a high $\mathrm{N}$ deposition region of the southern Rocky Mountains suggest that talus age contributes, in part, to differences in watershed retention of $\mathrm{N}(13,41)$. 

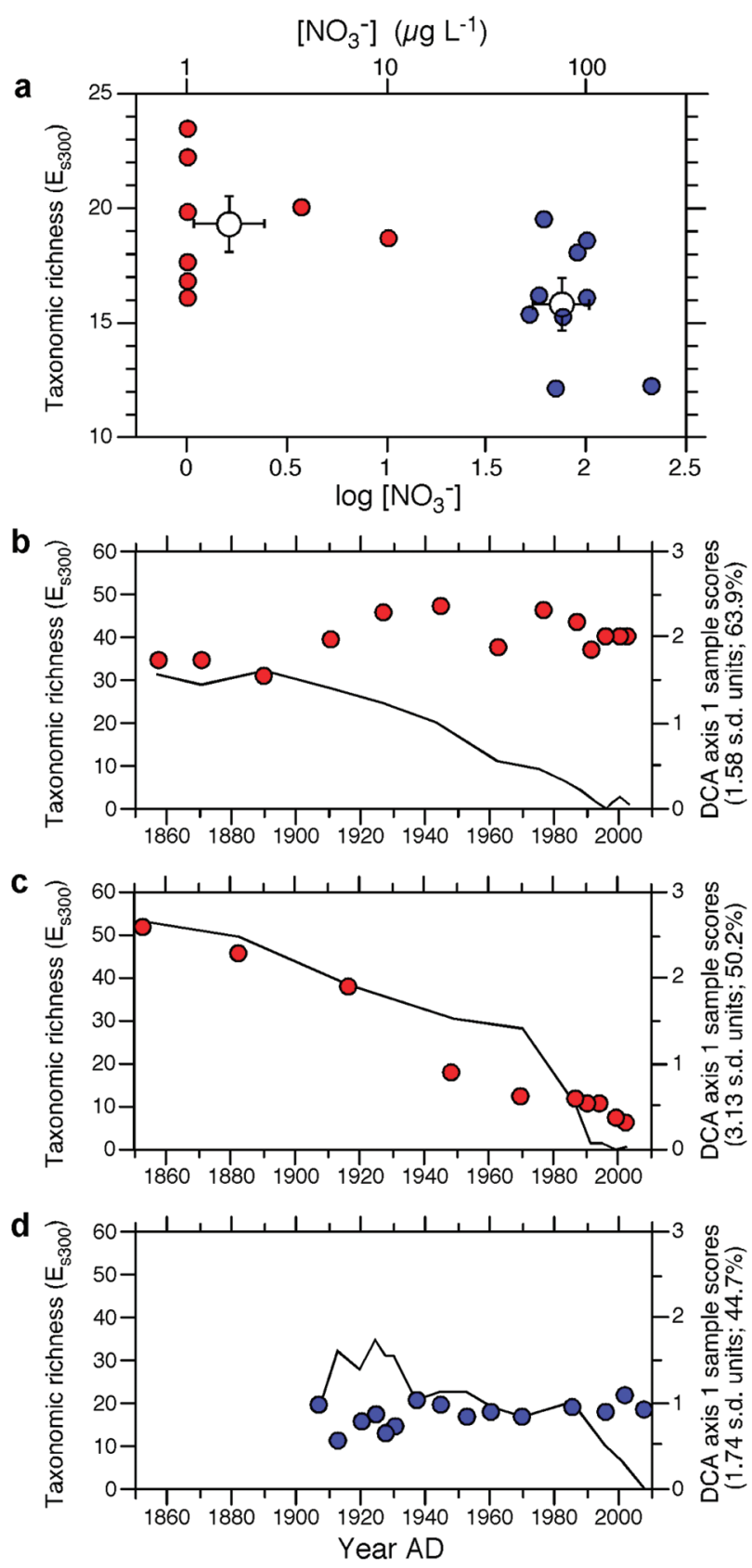

FIGURE 5. Taxonomic richness of sediment diatom assemblages based on rarefaction analysis (based on $n=300$ $\left(E_{S 300}\right)$ for every sample). (A) species richness versus $\log \left[\mathrm{NO}_{3}{ }^{-}\right]$ across surface sediment samples from GSF (blue) and SF (red) lakes, with the mean \pm one standard error indicated with an open symbol for each group. Additional plots portray the temporal evolution of diatom taxonomic richness (circles) and detrended correspondence analysis (DCA) first-axis sample scores (line) gleaned from ${ }^{210} \mathrm{~Pb}$-dated sediment cores from $(B)$ Beauty Lake (SF); (C) Emerald Lake (SF lake with pronounced late 20th-century nitrogen deposition); and (D) Rainbow Lake (GSF).

Our results demonstrate that the presence of glacier ice in alpine watersheds of the American Rocky Mountains more strongly influences $\mathrm{NO}_{3}{ }^{-}$concentrations in high-elevation lake ecosystems than any other geomorphic or biogeographic characteristic. Several key ecological features, including nutrient limitation patterns and species richness of a major algal group, differ between glacially influenced and snowpack-fed lakes. The mosaic of remaining glaciers in the central and northern Rockies therefore creates complex and heterogeneous geographic patterns of nutrient limitation and biogeochemical processes. Given predictions that alpine glaciers will disappear from the U.S. Rockies by 2030 (20), these observations raise serious questions concerning the future biogeochemical and ecological trajectories of hundreds of lake ecosystems within this vast region.

\section{Acknowledgments}

We thank Karl Kreutz for advice on glacial sampling and for useful discussions throughout the project. Gilbert Fulford and Trisha Spanbauer contributed diatom counts on two of the sediment cores. Dennis Anderson analyzed nutrient samples, and Kristin Ditzler assisted with figures. Carmen Daggett, Barnaby Olson, Randall Perry, Jonathan Rose and Courtney Wigdahl provided valuable field assistance. Comments from four anonymous reviewers on an earlier version of this manuscript were very helpful in strengthening this manuscript. This project was funded by the U.S. National Science Foundation (DEB-0734277). Funding for surface sediment diatom counts was provided by the National Park Service, U.S. Geological Survey, the U.S. Environmental Protection Agency, and the Natural Sciences and Engineering Research Council of Canada.

\section{Supporting Information Available}

Comprehensive tables of the 21 land cover classes delineated in this study as well as lake name, elevation, watershed area, lake area, nutrient chemistry, percent watershed coverage by perennial ice and talus, and named glaciers for each lake are provided. This material is available free of charge via the Internet at http://pubs.acs.org.

\section{Literature Cited}

(1) Key, C. H.; Fagre, D. B.; Menicke, R. K. Glacier retreat in Glacier National Park, Montana. In Satellite Image Atlas of Glaciers of the World, Glaciers of North America-glaciers of the Western United States; Williams, R. S., Jr., Ferrigno, J. G., Eds.; United States Government Printing Office: Washington, DC, 2002.

(2) Paul, F.; Kääb, A.; Maisch, M.; Kellenberger, T.; Haeberli, W. Rapid disintegration of alpine glaciers observed with satellite data. Geophys. Res. Lett. 2004, 31, L21402.

(3) Casassa, G.; Lopez, B.; Pouyard, B.; Escobar, F. Detection of changes in glacial runoff in alpine basins: examples from North America, the Alps, Central Asia, and the Andes. Hydrol. Processes 2009, 23, 31-41.

(4) Moore, R. D.; Fleming, S. W.; Menounos, B.; Wheate, R.; Fountain, A.; Stahl, K.; Holm, K.; Jakob, M. Glacier change in western North America: Implications for hydrology, geomorphic hazards and water quality. Hydrol. Processes 2009, 23, 42-61.

(5) Lafreniere, M. J.; Sharp, M. J. A comparison of solute fluxes and sources from glacial and non-glacial catchments over contrasting melt seasons. Hydrol. Processes 2005, 19, 2991-3012.

(6) Hood, E.; Scott, D. Riverine organic matter and nutrients in southeast Alaska affected by glacial coverage. Nat. Geosci. 2008, $1,583-587$.

(7) Baron, J. S.; Schmidt, T. M.; Hartman, M. D. Climate-induced changes in high elevation stream nitrate dynamics. Global Change Biol. 2009, 15, 1777-1789.

(8) Barnett, T. P.; Adam, J. C.; Lettenmaier, D. P. Potential impacts of a warming climate on water availability in snow-dominated regions. Nature 2005, 438, 303-309.

(9) Carey, M. Living and dying with glaciers: people's historical vulnerability to avalanches and outburst floods in Peru. Global Planet. Change 2005, 47, 122-134.

(10) Schindler, D. W.; Donahue, W. F. An impending water crisis in Canada's western prairie provinces. Proc. Natl. Acad. Sci. U.S.A. 2006, 103, 7210-7216.

(11) Thies, H.; Nickus, U.; Mair, V.; Tessadri, R.; Tait, D.; Thaler, B.; Psenner, R. Unexpected response of high alpine lake waters to climate warming. Environ. Sci. Technol. 2007, 41, 7424-7429.

(12) Blais, J. M.; Schindler, D. W.; Muir, D. C. G.; Sharp, M.; Donald, D.; Lafreniere, M.; Braekevelt, E.; Strachan, W. M. J. Melting glaciers: a major source of persistent organochlorines to subalpine Bow Lake in Banff National Park, Canada. Ambio 2001, 30, 410-415.

(13) Williams, M. W.; Knauf, M.; Cory, R.; Caine, N.; Liu, F. Nitrate content and potential microbial signature of rock glacier outflow, 
Colorado Front Range. Earth Surf. Process. Landforms 2007, 32, 1032-1047.

(14) Baron, J. S.; Rueth, H. M.; Wolfe, A. P.; Nydick, K. R.; Allstott, E. J.; Minear, J. T.; Moraska, B. Ecosystem responses to nitrogen deposition in the Colorado Front Range. Ecosystems 2000, 3, 352-368.

(15) Morris, D. P.; Lewis, W. M., Jr. Phytoplankton nutrient limitation in Colorado mountain lakes. Freshwater Biol. 1988, 20, 315327.

(16) Saros, J. E.; Michel, T. J.; Interlandi, S.; Wolfe, A. P. Resource requirements of Asterionella formosa and Fragilaria crotonensis in oligotrophic alpine lakes: implications for recent phytoplankton community reorganizations. Can.J. Fish. Aquat. Sci. 2005, 62, 1681-1689.

(17) Nanus, L.; Campbell, D. H.; Ingersoll, G. P.; Clow, D. W.; Mast M. A. Atmospheric deposition maps for the Rocky Mountains. Atmos. Environ. 2003, 37, 4881-4892.

(18) Dyson, J. L. Recent glacier recession in Glacier National Park, Montana. J. Geol 1941, 49, 815-824.

(19) Seifert, D.; Chatelain, E.; Lee, C.; Seligman, Z.; Evans, D.; Fisk, H.; Maus, P. Monitoring Alpine Climate Change in the Beartooth Mountains of the Custer National fForest; U.S. Department of Agriculture: Salt Lake City, 2009.

(20) Hall, M. H. P.; Fagre, D. B. Modeled climate-induced glacier change in Glacier National Park, 1850-2100. Bioscience 2003, $53,131-140$.

(21) United States Geological Survey: Northwest GAP Analysis Program. Available at http://gap.uidaho.edu/index.php/gaphome/Northwest-GAP (accessed Oct 2009).

(22) United States Geological Survey: National Elevation Dataset. Available at http://ned.usgs.gov (accessed Oct 2009).

(23) Daly, C.; Nielson, R. P.; Phillips, D. L. A statistical-topographic model for mapping climatological precipitation over mountainous terrain. J. Appl. Meteorol. 1994, 33, 140-158.

(24) Kirk, J. T. O. Light \& Photosynthesis in Aquatic Ecosystems; Cambridge University Press: New York, 1994.

(25) Morris, D. P.; Zagarese, H.; Williamson, C. E.; Balseiro, E. G.; Hargreaves, B. R.; Modenutti, B.; Moeller, R.; Queimalinos, C. The attenuation of solar UV radiation in lakes and the role of dissolved organic carbon. Limnol. Oceanogr. 1995, 40, 13811391.

(26) Rose, K. C.; Williamson, C. E.; Saros, J. E.; Sommaruga, R.; Fischer, J. M. Differences in UV transparency and thermal structure between alpine and subalpine lakes: implications for organisms. Photochem. Photobiol. Sci. 2009, 8, 1244-1256.

(27) Hall, R. I.; Smol, J. P. A weighted-averaging regression and calibration model for inferring total phosphorus concentration from diatoms in British Columbia (Canada) lakes. Freshwater Biol. 1992, 27, 417-434.
(28) Wolfe, A. P.; Baron, J. S.; Cornett, R. J. Anthropogenic nitrogen deposition induces rapid ecological changes in alpine lakes of the Colorado Front Range (USA). J. Paleolimnol. 2001, 25, 1-7.

(29) Stuiver, M.; Reimer, P. J. Extended 14C database and revised CALIB radiocarbon calibration program. Radiocarbon 1993, 35, 215-230.

(30) Birks, H. J. B.; Line, J. M. The use of rarefaction analysis for estimating palynological richness from Quaternary pollenanalytical data. The Holocene 1992, 2, 1-10.

(31) Hill, M. O.; Gauch, H. G. Detrended correspondence analysis, an improved ordination technique. Vegetatio 1980, 42, 47-58.

(32) Bergström, A. The use of TN:TP and DIN:TP ratios as indicators of phytoplankton nutrient limitation in oligotrophic lakes affected by N deposition. Aquat. Sci. 2010, doi: $10.1007 /$ s00027010-0132-0.

(33) Mayewski, P. A.; Lyons, W. B.; Spencer, M. J.; Twickler, M.; Dansgaard, W.; Koci, B.; Davidson, C. I.; Honrath, R. E. Sulfate and nitrate concentrations from a south Greeland ice core. Science 1988, 232, 975-977.

(34) Brimblecombe, P.; Tranter, M.; Abrahams, P. W.; Blackwood, I.; Davies, T. D.; Vincent, C. E. Relocation and preferential elution of acidic solute through the snowpack of a small remote, high altitude Scottish catchment. Ann. Glaciol. 1985, 7, 141-147.

(35) Schuster, P. F.; White, D. E.; Naftz, D. L.; Cecil, L. D. Chronological refinement of an ice core record at Upper Fremont Glacier in south central North America. J. Geophys. Res. 2000, 105, 46574666.

(36) Daly, G. L.; Wania, F. Organic contaminants in mountains. Environ. Sci. Technol. 2005, 39, 385-398.

(37) Brooks, P. D.; Williams, M. W.; Schmidt, S. K. Microbial activity under alpine snowpacks, Niwot Ridge, Colorado. Biogeochemistry 1996, 32, 92-113.

(38) Wynn, P. M.; Hodson, A. J.; Heaton, T. H. E.; Chenery, S. R. Nitrate production beneath a High Arctic glacier, Svalbard. Chem. Geol. 2007, 244, 88-102.

(39) Engstrom, D. R.; Fritz, S. C.; Almendinger, J. E.; Juggins, S. Chemical and biological trends during lake evolution in recently deglaciated terrain. Nature 2000, 408, 161-166.

(40) Fritz, S. C.; Engstrom, D. R.; Juggins, S. Patterns of early lake evolution in boreal landscapes: a comparison of stratigraphic inferences with a modern chronosequence in Glacier Bay, Alaska. Holocene 2004, 14, 828-840.

(41) Clow, D. W.; Sueker, J. K. Relations between basin characteristics and stream-water chemistry in alpine/subalpine basins in Rocky Mountain National Park, Colorado. Water Resour. Res. 2000, $36,49-61$.

ES100147J 